\title{
PENAMBAHAN ISOLAT PROTEIN KEDELE DAN SUKROSA SEBAGAI ELISITOR TERHADAP SENYAWA ANTIOKSIDAN DAN RACUN PADA KECAMBAH KORO KOMAK (Lablab purpureus L Sweet)
}

\author{
Sukatiningsih ${ }^{1,}$ Kurniawan $^{2}$, Windrati ${ }^{1}$ \\ ${ }^{1}$ Staf pengajar Fakultas Teknologi Pertanian Universitas Jember \\ ${ }^{2}$ Alumni Fakultas Teknologi Pertanian Universitas Jember \\ Korespondensi : Fakultas Teknologi Pertanian, Universitas Jember, Jl.Kalimantan 37 Jember \\ Email : sukatiftp@yahoo.com
}

\begin{abstract}
The germination of " koro komak" with elicitation can improve antioxidant substance. Sucrose and ISP on concentration 0, 500, 1000, 1500, 2000 ppm were use as elicitor. The obyective of this research were to know the effect of the kind and the concentration of elicitor to the value of antioxidant substance and the best time of germination produced maximal antioxidant and minimum toxic substance.The result of this research was the kind and the concentration of elicitor influence antioxidant substance and one day is the best time of germination.
\end{abstract}

Key word : komak, sprout, elicitor,antioxsidant

\section{PENDAHULUAN}

Biji koro-koroan merupakan tanaman bijian terpenting kedua sebagai sumber pangan utama dunia (Rubatzky dan Yamaguchi, 1997). Salah satu spesies korokoroan yang banyak terdapat di Indonesia adalah koro komak (Lablab purpureus (L) Sweet). Tanaman koro komak atau koro wedhus mudah dibudidayakan dan produksinya mencapai $2.600-4.500 \mathrm{~kg} / \mathrm{ha}$. Biji koro komak mengandung protein yang cukup tinggi, sekitar 20-25\%. Sedangkan kandungan lemaknya sangat rendah yaitu antara 0,2-3\% dan kandungan karbohidratnya relatif tinggi, yaitu 50-60\% (Maensen dan Somaatmadja, 1993).

Koro komak mengandung zat gizi seperti karbohidrat, protein, dan serat yang tinggi sehingga berpotensi untuk dikembangkan sebagai sumber bahan pangan fungsional (Maensen dan Somaatmadja, 1993). Karena banyak keistimewaan yang terdapat pada koro komak maka mulai banyak dilakukan berbagai macam penelitian yang bertujuan untuk meningkatkan karakteristik mutu termasuk peningkatan kadar antioksidan dan aktivitas antioksidan koro komak.

Menurut Vanderstoep dalam Supriyanto (1998), nilai gizi biji-bijian dapat ditingkatkan dengan proses perkecambahan. Perkecambahan diketahui dapat meningkatkan kadar senyawa antioksidan dan aktivitas antioksidan koro komak. Proses perkecambahan adalah permulaan pertumbuhan embrio yang aktif sehingga menyebabkan kulit biji menjadi pecah kemudian tumbuh tunas kecambah (redikula) (Copeland dalam Supriyanto, 1998). Pada proses perkecambahan akan menyebabkan berkurangnya atau hilangnya senyawa racun serta senyawa anti gizi serta meningkatkan kadar polifenol (Sutardi, 1998). Selain itu, pada saat perkecambahan terjadi proses hidrolisis karbohidrat dan lemak menjadi senyawa lebih sederhana sehingga dapat meningkatkan daya cerna pada proses pencernaan manusia (Sutardi, 1998). Perkecambahan dipengaruhi oleh beberapa faktor antara lain: kadar air, komposisi udara, suhu, cahaya, dan waktu (Susanto dan Saneto, 1994). Aktifitas antioksidan pada kecambah juga dipengaruhi oleh faktor-faktor tersebut dimana waktu perkecambahan mempunyai suatu titik optimum. Perkecambahan melebihi waktu optimum justru akan menyebabkan turunnya aktifitas antioksidan. Hal tersebut disebabkan senyawa fenol diubah menjadi lignin (Randhir et al., 2004).

Untuk meningkatkan produksi metabolit sekunder pada biji maka di dalam proses perkecambahan digunakan teknik elisitasi yaitu dengan menambahkan elisitor 
pada saat perlakuan perendaman biji. Elisitasi merupakan proses penambahan elisitor pada sel tumbuhan dengan tujuan untuk menginduksi dan meningkatkan pembentukan metabolit sekunder (Fitriani, 2003). Elisitor merupakan penyebab adanya sinyal yang mengaktifkan enzim-enzim yang kemudian mengkatalis metabolisme pembentuk metabolit sekunder (Yuliana, 2003). Elisitor yang digunakan adalah isolat protein kedele (IPK) dan sukrosa.

Penelitian tentang karakteristik mutu kecambah koro komak menggunakan elisitor belum pernah dilakukan sehingga dalam penelitian ini akan dilakukan perlakuan perendaman pada biji koro komak dengan menggunakan elisitor larutan IPK dan sukrosa dalam berbagai variasi konsentrasi serta waktu perkecambahan. Untuk melengkapi informasi, pada perlakuan yang terpilih diamati daya cerna pati, protein serta analisa proksimatnya.

\section{METODE PENELITIAN}

\section{Bahan dan Alat Penelitian}

\section{Bahan}

Bahan utama yang digunakan dalam penelitian ini adalah biji koro komak putih etanol, AgNO3, K-tiosianat, indikator Feri, larutan Iodin, reagen Follin-ciocalteau, DPPH (difenil pikrilhidrasil), petroleum eter, $\mathrm{Na}_{2} \mathrm{Co}_{3}, \mathrm{H}_{2} \mathrm{SO}_{4}, \mathrm{~K}_{2} \mathrm{SO}_{4}, \mathrm{NaOH}, \mathrm{HCl}, \mathrm{HNO}_{3}$, $\mathrm{FeCl}_{3}$, asam dinitrosalisilat (DNS), Na-fosfat, asam borat, selenium

\section{Alat}

Peralatan yang diperlukan dalam menunjang penelitian ini adalah sebagai berikut : keranjang plastik berlubang, gelas bekas minuman kemasan, kain saring, karung goni, karet gelang, mortar, timbangan analitik, peralatan gelas,, spektrofotometer (Secoman version 1,10), sentrifuge, mikropipet Eppendorf, desikator, oven, eksikator, kertas saring, stirer, vortex, cawan porselin.

\section{Rancangan penelitian}

Penelitian menggunakan Metode

Rancangan Acak Kelompok (RAK) yang terdiri dari dua faktor dan tiga ulangan. Faktor perlakuan yang digunakan adalah jenis elisitor
(A) dan konsentrasi elisitor (B) dengan taraf sebagai berikut:

FaktorA : Jenis Elisitor

$\mathrm{A}_{1} \quad: \quad$ Isolat Protein

kedele (IPK)

$\begin{array}{ccc}\mathrm{A}_{2} & : & \text { Sukrosa } \\ \text { FaktorB } & : & \text { Konsentrasi }\end{array}$

Elisitor

$\begin{array}{llrl}\mathrm{B}_{1} & : & 0 & \mathrm{ppm} \\ \mathrm{B}_{2} & : & 500 & \mathrm{ppm} \\ \mathrm{B}_{3} & : & 1.000 & \mathrm{ppm} \\ \mathrm{B}_{4} & : & 1.500 & \mathrm{ppm} \\ \mathrm{B}_{5} & : & 2.000 & \mathrm{ppm}\end{array}$

Dari kedua faktor diperoleh

kombinasi perlakuan sebagai berikut:

$A_{1} B_{1} ; A_{1} B_{2} ; A_{1} B_{3} ; A_{1} B_{4} ; A_{1} B_{5}$

$\mathrm{A}_{2} \mathrm{~B}_{1} ; \mathrm{A}_{2} \mathrm{~B}_{2} ; \mathrm{A}_{2} \mathrm{~B}_{3} ; \mathrm{A}_{2} \mathrm{~B}_{4} ; \mathrm{A}_{2} \mathrm{~B}_{5}$

Data yang diperoleh digambarkan histogramnya serta dianalisis menggunakan analisis sidik ragam dan bila ada perbedaan maka dilanjutkan dengan Uji Beda Nyata menggunakan uji DMRT (Duncan's Multiple Range Test) dengan $\alpha=5 \%$ (Gasperz, 1991).

\section{Parameter Pengamatan}

Parameter yang diamati pada perkecambahan koro komak antara lain :

Kadar Vitamin C (Sudarmadji dkk., 1997), kadar $\beta$-Karoten (Tejasari,dkk, 2006), total Polifenol (Andarwulan dkk., 1999), aktifitas antioksidan (Gadow et al., 1997),kadar HCN , Air , abu (Sudarmadji dkk., 1997), Analisa Proksimat (Subagio, dkk 2002 ),daya cerna pati dan daya cerna protein cara Enzimatis (Tejasari dkk., 2006)

\section{Pelaksanaan Penelitian}

Penelitian Apriliana

menggunakan perlakuan elisitor sukrosa pada berbagai konsentrasi yaitu 0, 500, 1000, 1500 dan 2000 ppm .Perlakuan pada penelitian ini digunakan jenis elisitor sukrosa dan IPK pada variasi konsentrasi sama. Sebanyak 100 biji koro komak dengan berat $\pm 2,75$ gram dimasukkan dalam gelas aqua yang berisi larutan elisitor sekitar $150 \mathrm{ml}$ (sampai semua biji terendam). Kemudian direndam selama 24 jam. Perendaman dilakukan sesuai dengan berbagai konsentrasi dari masing-masing elisitor, yaitu $0,500,1.000,1.500$, dan 2.000 ppm. Lama perendaman 24 jam dan setiap 6 jam sekali larutan elisitor diganti dengan larutan elisitor yang baru. Setelah 24 jam direndam, kemudian dilakukan penirisan lalu 
biji koro komak ditempatkan pada keranjang berlubang yang dialasi dengan dua lembar karung goni. Setelah itu, biji koro komak dikenakan sinar matahari selama 1 jam atau lebih. Setelah 1 jam dijemur, wadah keranjang ditutup dengan satu lembar karung goni. Lama perkecambahan 24 jam dan setiap pagi dan sore hari disiram. Setelah 24 jam perkecambahan tepatnya pada hari pertama perkecambahan, kecambah biji koro diambil, ditimbang beratnya lalu dimasukkan ke dalam freezer. Selanjutnya pada hari kedua dan ketiga perkecambahan dilakukan hal serupa.

Pada kecambah koro komak dilakukan analisa yang meliputi: kadar vitamin $\mathrm{C}$, kadar $\beta$-karoten, total polifenol, aktifitas antioksidan (DPPH), kadar HCN. Pada perlakuan terbaik dilakukan analisa proksimat, daya cerna protein, dan daya cerna pati.

\section{HASIL DAN PEMBAHASAN}

\section{Kadar Vitamin C}

Kadar vitamin C kecambah koro komak dengan teknik elisitasi dapat dilihat pada Gambar 1 dan Gambar 2. Gambar 1 menunjukkan bahwa kadar vitamin $\mathrm{C}$ kecambah koro komak meningkat paling tinggi pada 1 hari perkecambahan (24 jam), kadar vitamin $\mathrm{C}$ terus menurun dari 1 hari, 2 hari, dan 3 hari perkecambahan. Sehingga pada 1 hari perkecambahan dianggap yang terbaik. Kadar vitamin C kecambah koro komak yang tertinggi dengan elisitor IPK terdapat pada 1 hari perkecambahan dengan konsentrasi elisitor $1.500 \mathrm{ppm}$ sebesar 1,905 $\mathrm{mg} / \mathrm{g}$. Begitu juga dengan elisitor sukrosa diperoleh kadar vitamin $\mathrm{C}$ tertinggi pada 1 hari perkecambahan dengan konsentrasi 1.500 ppm sebesar 1,409 mg/g.

Uji beda kadar Vitamin C kecambah komak pada variasi jenis elisitor seperti terlihat pada Tabel 1.

Kemampuan IPK dalam menyerap dan mengikat air lebih tinggi dibanding sukrosa, sehingga elisitor IPK lebih efektif dalam mengaktivasi enzim gulunolakton oksidase yang terdapat dalam kecambah koro komak dan menyebabkan sintesa vitamin $\mathrm{C}$ oleh enzim gulunolakton oksidase semakin meningkat.
Uji beda kadar vitamin $\mathrm{C}$ kecambah koro komak pada variasi konsentrasi elisitor dapat dilihat pada Tabel 2.

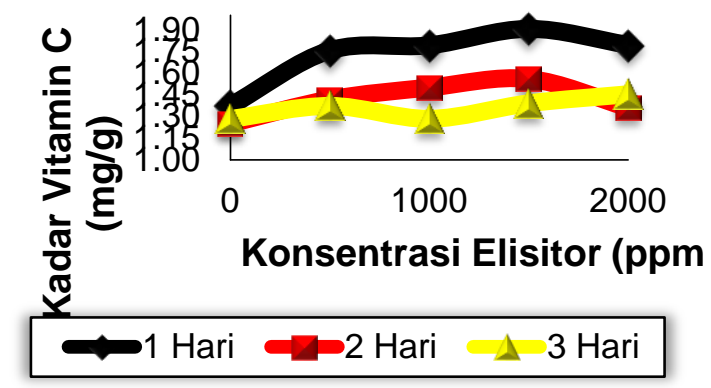

Gambar 1. Kadar Vitamin C Kecambah Koro Komak dengan elisitor IPK

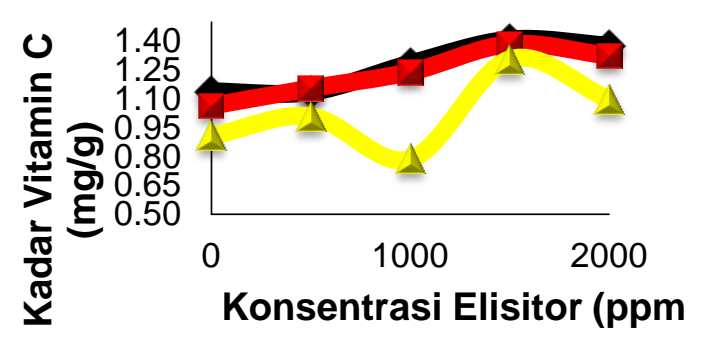

$\longrightarrow$ 1 Hari $\square$ 2 Hari $\triangle 3$ Hari

Gambar 2. Kadar Vitamin C Kecambah Koro Komak dengan Elisitor Sukrosa

Tabel 1. Uji Beda Kadar Vitamin C, $\beta$ karoten, Polifenol, aktivitas antioksidan, $\mathrm{HCN}$ Kecambah Koro Komak pada Variasi Jenis Elisitor

\begin{tabular}{ccccc}
\hline Elisitor & $\begin{array}{c}\text { Vitami } \\
\mathrm{n} \mathrm{C} \\
(\mathrm{mg} / \mathrm{g})\end{array}$ & $\begin{array}{c}\text { B karoten } \\
(\mu \mathrm{g} / \mathrm{g})\end{array}$ & $\begin{array}{c}\text { Polifenol } \\
(\mu \mathrm{mol} / \mathrm{m} \\
\mathrm{g})\end{array}$ & $\begin{array}{c}\text { Aktivitas } \\
\text { antioksid } \\
\text { an } \\
(\mu \mathrm{mol} / \mathrm{g})\end{array}$ \\
\hline ISP & $1,724 \mathrm{a}$ & $0,040 \mathrm{~b}$ & $0,029 \mathrm{~b}$ & $2,354 \mathrm{a}$ \\
Sukrosa & $1,269 \mathrm{~b}$ & $0,158 \mathrm{a}$ & $0,038 \mathrm{a}$ & $2,316 \mathrm{a}$ \\
\hline
\end{tabular}

Keterangan : Huruf yang sama menunjukkan berbeda tidak nyata pada uji Duncan tingkat kepercayaan $95 \%$

Dari Tabel 2. dapat dilihat bahwa kadar vitamin $\mathrm{C}$ meningkat seiring dengan peningkatan konsentrasi elisitor sampai pada batas $1.500 \mathrm{ppm}$. Namun, kadar vitamin $\mathrm{C}$ menurun pada konsentrasi elisitor 2.000 ppm. Peningkatan kadar vitamin $\mathrm{C}$ diduga karena adanya kemampuan elisitor IPK dan sukrosa dalam mengikat air. Semakin tinggi konsentrasi elisitor IPK dan sukrosa, makin 
banyak air yang terikat maka kerja enzim akan semakin aktif.

Menurut Gupta dalam Setyati (1999), air mengaktifkan bermacam-macam enzim dan memungkinkan pemecahan bermacam-macam cadangan makanan di samping sebagai alat transportasi makanan dari endosperm ke meristem pada sumbu embrio untuk membentuk protoplasma baru. Jadi semakin banyak air yang tersedia, makin meningkatkan aktivitas enzim Lgulunolakton oksidase yang berperanan dalam mengkonversi L-gulunolakton ke bentuk 2keto-L-gulunolakton, sebagai tahap akhir dalam sintesis vitamin $\mathrm{C}$ sehingga kadar vitamin $\mathrm{C}$ akan meningkat selama perkecambahan. Hal ini sesuai dengan konsep elisitor menurut Yuliana (2003), yaitu elisitor merupakan penyebab adanya sinyal yang mengaktifkan enzim-enzim yang kemudian mengkatalis metabolisme pembentuk metabolit sekunder.

Penurunan kadar vitamin C pada pemberian elisitor konsentrasi 2.000 ppm diduga karena jaringan koro komak kurang efektif dalam menyerap elisitor pada konsentrasi larutan yang pekat. Akibatnya, sinyal induksi yang akan mengaktifkan enzim pensintesa vitamin $\mathrm{C}$ tidak tersampaikan dengan optimal, sehingga sintesa vitamin $\mathrm{C}$ juga akan terhambat (Setyati, 1999).

Uji beda kadar vitamin $C$ kecambah koro komak pada variasi jenis dan konsentrasi elisitor dapat dilihat pada Tabel 3.

Tabel 3. Uji beda senyawa dan aktivitas antioksidan kecambah koro

\begin{tabular}{ccccc}
\hline $\begin{array}{c}\text { Perlaku } \\
\text { an }\end{array}$ & $\begin{array}{c}\text { vit.C } \\
(\mathrm{mg} / \mathrm{g})\end{array}$ & $\begin{array}{c}\text { B karoten } \\
(\mu \mathrm{g} / \mathrm{g})\end{array}$ & $\begin{array}{c}\text { Total } \\
\text { Polifenol } \\
(\mu \mathrm{mol} / \mathrm{mg})\end{array}$ & $\begin{array}{c}\text { Aktivitas } \\
\text { antioksida } \\
\mathrm{n}(\mu \mathrm{mol} / \mathrm{g})\end{array}$ \\
\hline A1B1 & $1,373 \mathrm{efg}$ & $\begin{array}{c}0,026 \\
\text { fghi }\end{array}$ & $0,020 \mathrm{j}$ & $2,207 \mathrm{i}$ \\
A1B2 & $1,756 \mathrm{bcd}$ & $0,038 \mathrm{fgh}$ & $0,028 \mathrm{hi}$ & $2,350 \mathrm{bcd}$ \\
A1B3 & $1,791 \mathrm{abc}$ & $0,042 \mathrm{fgh}$ & $0,030 \mathrm{fgh}$ & $2,384 \mathrm{abc}$ \\
A1B4 & $1,905 \mathrm{a}$ & $0,047 \mathrm{fg}$ & $0,032 \mathrm{def}$ & $2,435 \mathrm{a}$ \\
A1B5 & $1,794 \mathrm{ab}$ & $0,045 \mathrm{f}$ & $0,033 \mathrm{~d}$ & $2,393 \mathrm{ab}$ \\
A2B1 & $1,136 \mathrm{hi}$ & $0,104 \mathrm{de}$ & $0,032 \mathrm{def}$ & $2,236 \mathrm{hi}$ \\
A2B2 & $1,136 \mathrm{hi}$ & $0,125 \mathrm{~cd}$ & $0,039 \mathrm{bc}$ & $2,348 \mathrm{bcd}$ \\
A2B3 & $1,284 \mathrm{fgh}$ & $0,155 \mathrm{bc}$ & $0,041 \mathrm{ab}$ & $2,296 \mathrm{defg}$ \\
A2B4 & $1,409 \mathrm{e}$ & $0,216 \mathrm{a}$ & $0,042 \mathrm{a}$ & $2,334 \mathrm{bcde}$ \\
A2B5 & $1,377 \mathrm{ef}$ & $1,191 \mathrm{ab}$ & &
\end{tabular}

Keterangan : huruf yang sama menunjukkan berbeda tidak nyata pada tingkat kepercayaan $95 \%$

Dari Tabel 3. menunjukkan kadar vitamin C kecambah koro komak yang tertinggi pada perlakuan A1B4 (jenis elisitor: IPK dan konsentrasi elisitor $=1.500 \mathrm{ppm}$ ) sebesar $1,905 \mathrm{mg} / \mathrm{g}$, sedangkan kadar vitamin $\mathrm{C}$ terendah terdapat pada perlakuan A2B2 (jenis elisitor: sukrosa dan konsentrasi elisitor $=1.000 \mathrm{ppm}$ ) sebesar $1,136 \mathrm{mg} / \mathrm{g}$.

\section{Kadar $\beta$-Karoten}

Kadar $\beta$-karoten kecambah koro komak dengan teknik elisitasi dapat dilihat pada Gambar 3 dan Gambar 4.

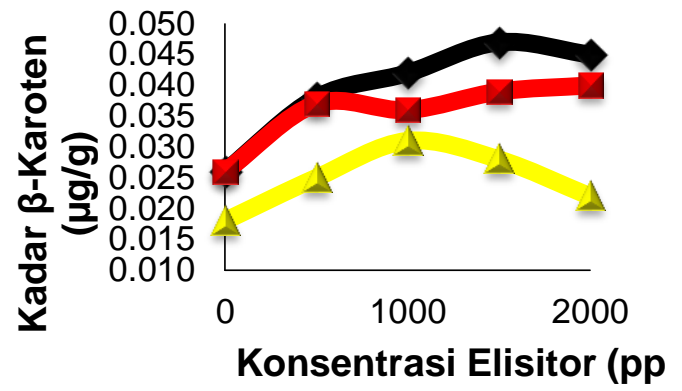

$\rightarrow$ 1 Hari $\rightarrow 2$ Hari $\Delta 3$ Hari

Gambar 3. Kadar $\beta$-Karoten Kecambah Koro Komak dengan elisitor IPK

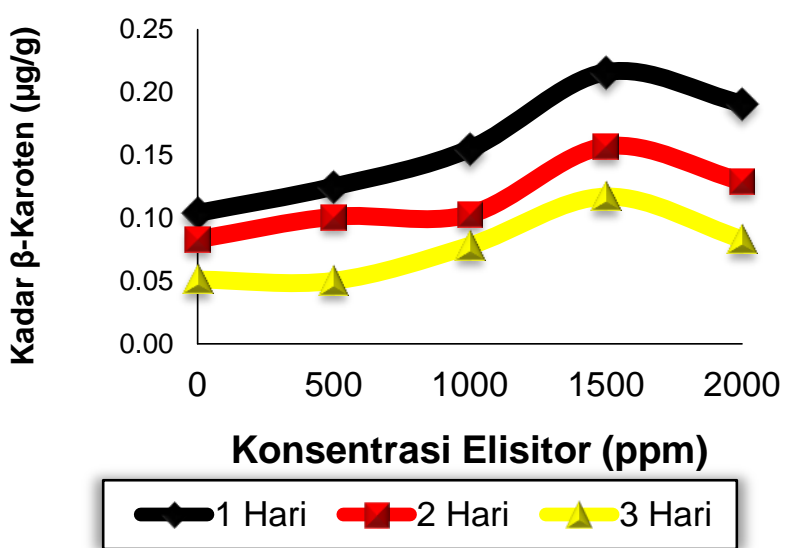

Gambar 4 Kadar $\beta$-Karoten Kecambah Koro Komak dengan Elisitor Sukrosa

Dari Gambar 3 dan Gambar 4. dapat diketahui bahwa kadar $\beta$-karoten kecambah koro komak meningkat paling tinggi pada 1 hari perkecambahan (24 jam). Dari kedua gambar di atas terlihat bahwa kadar $\beta$-karoten terus menurun dari 1 hari, 2 hari, dan 3 hari perkecambahan. Sehingga pada 1 hari perkecambahan dianggap yang terbaik untuk menghasilkan $\beta$-karoten. Kadar $\beta$-karoten 
kecambah koro komak tertinggi didapati pada elisitor IPK pada 1 hari perkecambahan dengan konsentrasi elisitor $1.500 \mathrm{ppm}$ sebesar $0,047 \mu \mathrm{g} / \mathrm{g}$. Begitu juga dengan elisitor sukrosa diperoleh kadar $\beta$-karoten tertinggi pada 1 hari perkecambahan dengan konsentrasi $1.500 \mathrm{ppm}$ sebesar 0,216 $\mu \mathrm{g} / \mathrm{g}$.

Dari Tabel 1 hasil pengamatan, kadar $\beta$-karoten kecambah koro komak dengan elisitor sukrosa lebih besar dibandingkan kadar $\beta$-karoten kecambah koro komak dengan elisitor IPK. Kadar $\beta$ karoten kecambah koro komak dengan elisitor IPK yaitu $0,0397 \mu \mathrm{g} / \mathrm{g}$ sedangkan untuk komak dengan elisitor sukrosa yaitu 0,1584 $\mu \mathrm{g} / \mathrm{g}$. Dengan ukuran molekul yang kecil , larutan sukrosa lebih mudah terserap oleh jaringan koro komak. Dengan demikian elisitor sukrosa lebih efektif dalam menginduksi enzim karotenase untuk mensintesis $\beta$-karoten.

Dari Tabel 2. dapat dilihat bahwa konsentrasi elisitor yang semakin tinggi maka kadar $\beta$-karoten yang dihasilkan semakin tinggi. Namun pada perlakuan B5 kadar $\beta$ karoten menurun. Peningkatan kadar $\beta$ karoten diduga karena penambahan elisitor pada perkecambahan koro komak memiliki peranan dalam transduksi sinyal sehingga mengaktifkan enzim karotenase dan menghasilkan metabolit sekunder, salah satunya berupa senyawa terpena. Diketahui bahwa $\beta$-karoten merupakan salah satu bentuk dari senyawa terpena (karoten).

Seperti halnya pengamatan parameter kadar vitamin $\mathrm{C}$, kadar $\beta$-karoten pada konsentrasi 2.000 ppm juga mengalami penurunan. Hal ini disebabkan karena jaringan koro komak telah jenuh. Terhadap elisitor, sehingga jika konsentrasinya ditingkatkan diatas konsentrasi optimal elisitor, biosintesis $\beta$-karoten menjadi berkurang.

Dari Tabel 3. menunjukkan kadar $\beta$ karoten kecambah koro komak yang tertinggi pada perlakuan A2B4 (jenis elisitor: sukrosa dan konsentrasi elisitor $=1.500 \mathrm{ppm}$ ) sebesar $0,2160 \mu \mathrm{g} / \mathrm{g}$, sedangkan kadar $\beta$-karoten terendah terdapat pada perlakuan A1B1 (jenis elisitor: IPK dan konsentrasi elisitor $=0 \mathrm{ppm}$ ) sebesar $0,0264 \mu \mathrm{g} / \mathrm{g}$.

\section{Total Polifenol}

Data hasil pengamatan terhadap. total polifenol kecambah koro komak dengan teknik elisitasi dapat dilihat pada Gambar 5 dan Gambar 6.

Dari Gambar 5 dan Gambar 6. terlihat bahwa total polifenol terus menurun dari 1 hari, 2 hari, dan 3 hari perkecambahan. Sehingga pada 1 hari perkecambahan dianggap yang terbaik untuk menghasilkan total polifenol. Total polifenol rerata kecambah koro komak tertinggi pada elisitor isolat protein terdapat pada 1 hari perkecambahan dengan konsentrasi elisitor $2.000 \mathrm{ppm}$ sebesar $0,033 \mu \mathrm{mol} / \mathrm{mg}$. Begitu juga dengan elisitor sukrosa diperoleh total polifenol tertinggi pada 1 hari perkecambahan dengan konsentrasi $2.000 \mathrm{ppm}$ sebesar 0,042 $\mu \mathrm{mol} / \mathrm{mg}$.

Dari Tabel 1. Total polifenol pada perlakuan A1 lebih rendah dibandingkan pada perlakuan A2. Total polifenol kecambah koro komak dengan elisitor IPK yaitu 0,0285 $\mu \mathrm{mol} / \mathrm{mg}$ sedangkan komak dengan elisitor sukrosa yaitu $0,0374 \mu \mathrm{mol} / \mathrm{mg}$. Selama perkecambahan sukrosa akan terhidrolisis membentuk glukosa. Glukosa akan melewati jalur glikolisis dan lintasan pentosa phospat, lebih lanjut oleh enzim guaiacol peroksidase (GPX) akan diubah menjadi senyawa fenolik. Kemudian akan disintesis menjadi senyawa polifenol. Menurut Vattem pada perkecambahan fava bean (kedelai) menggunakan elisitor akan meningkatkan sintesis fenolik pada jalur pentosa phosphat (Apriliana, 2007).

Dari Tabel 2. dapat dilihat bahwa dengan konsentrasi elisitor yang semakin tinggi maka total polifenol yang dihasilkan semakin tinggi. Menurut Contin et al. (1999), elisitor dapat meningkatkan kandungan metabolit sekunder dengan dua cara, yaitu meningkatkan aktivitas enzim dan meningkatkan sintesis enzim yang terlibat dalam jalur biosintesis metabolit tertentu. Maka diduga elisitor IPK dan sukrosa meningkatkan aktivitas enzim phenolase dalam mensintesis senyawa fenol sehingga total polifenol meningkat. Hasil penelitian ini sejalan dengan hasil penelitian Rhandir, et al (2004), bahwa elisitasi memberikan pengaruh terhadap peningkatan senyawa fenolik dan aktifitas antioksidan selama perkecambahan. 
Dari Tabel 3. menunjukkan total polifenol kecambah koro komak yang tertinggi pada perlakuan A2B5 (jenis elisitor: sukrosa dan konsentrasi elisitor $=2.000 \mathrm{ppm}$ ) sebesar $0,0423 \mu \mathrm{mol} / \mathrm{mg}$, sedangkan total polifenol terendah terdapat pada perlakuan A1B1 (jenis elisitor: IPK dan konsentrasi elisitor $=0 \mathrm{ppm}$ ) sebesar $0,0202 \mu \mathrm{mol} / \mathrm{mg}$.

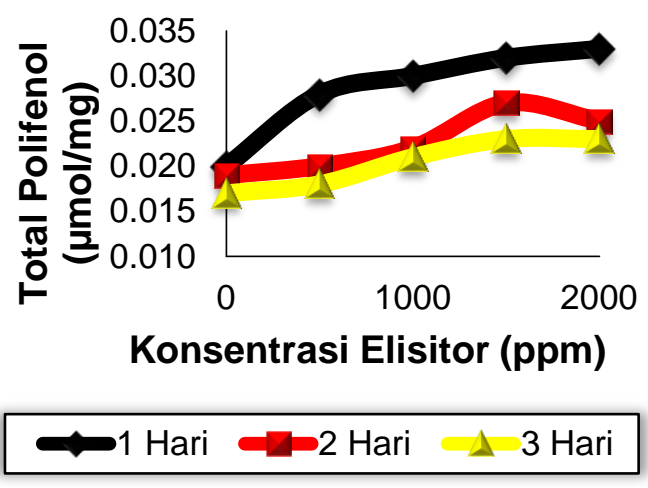

Gambar 5. Total Polifenol Kecambah Koro Komak dengan elisitor IPK

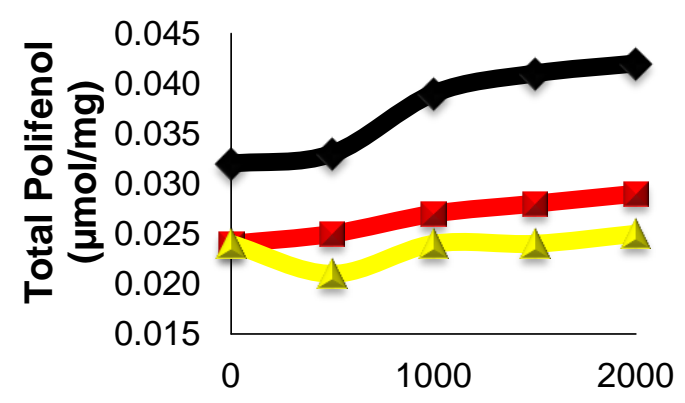

Konsentrasi Elisitor (ppm)

1 Hari $\quad 2$ Hari $\triangle 3$ Hari

Gambar 6 Total Polifenol Kecambah Koro Komak dengan Elisitor Sukrosa

\section{Aktivitas Antioksidan}

Aktivitas antioksidan kecambah koro komak dengan teknik elisitasi dapat dilihat pada Gambar 7 dan Gambar 8.

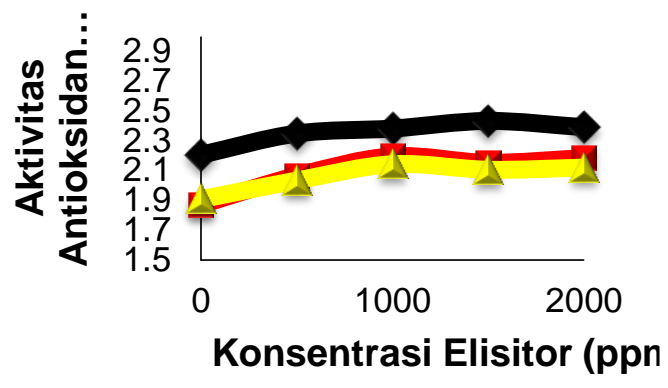

1 Hari -2 Hari $\Delta 3$ Hari

Gambar 7 Aktivitas Antioksidan Kecambah Koro Komak dengan elisitor IPK

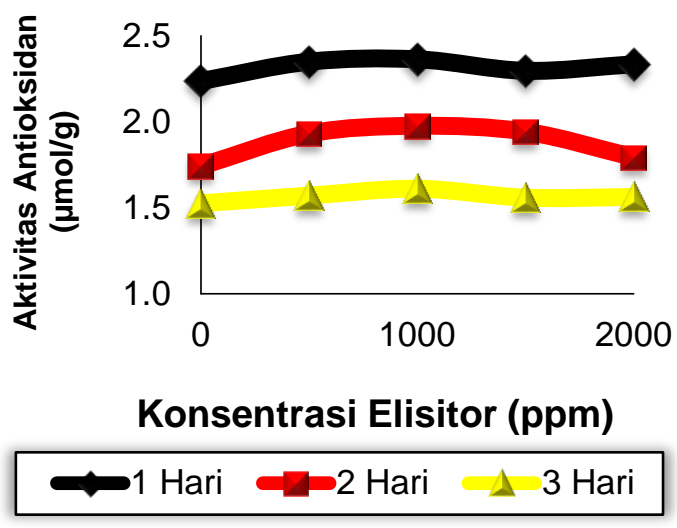

Gambar 8. Aktivitas Antioksidan Kecambah Koro Komak dengan Elisitor Sukrosa

Dari Gambar 7 dan Gambar 8. menunjukkan aktivitas antioksidan kecambah koro komak meningkat paling tinggi pada 1 hari perkecambahan (24 jam). Hal ini sejalan dengan peningkatan optimal vitamin $C, \beta-$ karoten, dan polifenol sehingga menyebabkan aktivitas antioksidannya juga meningkat. Dari Gambar 7 dan 8 terlihat bahwa aktivitas antioksidan terus menurun dari 1 hari, 2 hari, dan 3 hari perkecambahan. Sehingga pada 1 hari perkecambahan dianggap yang terbaik untuk menghasilkan aktivitas antioksidan yang optimal. Aktivitas antioksidan kecambah koro komak yang tertinggi dengan elisitor IPK terdapat pada 1 hari perkecambahan dengan konsentrasi elisitor $1.500 \mathrm{ppm}$ sebesar $2,435 \mu \mathrm{mol} / \mathrm{g}$. Begitu juga dengan elisitor sukrosa diperoleh aktivitas antioksidan tertinggi pada 1 hari perkecambahan dengan konsentrasi 2.000 ppm sebesar 2,334 $\mu \mathrm{mol} / \mathrm{g}$.

Dari Tabel 2 terlihat bahwa konsentrasi elisitor yang semakin tinggi maka 
aktivitas antioksidan yang dihasilkan semakin tinggi. Namun, pada perlakuan B4 dan B5 aktivitas antioksidan menurun. Meningkatnya aktivitas antioksidan seiring dengan meningkatnya senyawa antioksidan yang terbentuk. Menurut Bravo ( 1998) antioksidan fenol berperan dapat menghalangi proses oksidasi lipida dan molekul lain dengan menyumbangkan atom hidrogen pada radikal bebas (DPPH).

Menurut Gardner FP dalam Novijanto (1996), sukrosa yang termasuk dalam golongan oligosakarida dapat bersinergi dengan elisitor endogen pada tanaman yang kebanyakan juga merupakan golongan oligosakarida. Sehingga diduga penggunaan elisitor sukrosa lebih dapat meningkatkan aktivitas antioksidan kecambah koro komak. Perlakuan penjemuran selama perkecambahan memungkinkan peningkatkan hidroksimetilfural (intermediet produksi MRP), yang kemudian akan membuat aktivitas antioksidan koro komak meningkat. (Soong dan Barlow, 2004).

Dari Tabel 3. menunjukkan aktivitas antioksidan kecambah koro komak yang tertinggi pada perlakuan A1B4 (jenis elisitor: IPK dan konsentrasi elisitor $=1.500$ $\mathrm{ppm})$ sebesar $2,4350 \mu \mathrm{mol} / \mathrm{g}$, sedangkan aktivitas antioksidan terendah terdapat pada perlakuan A1B1 (jenis elisitor: IPK dan konsentrasi elisitor $=0 \mathrm{ppm}$ ) sebesar 2,2068 $\mu$ $\mathrm{mol} / \mathrm{g}$.

\section{Kadar HCN}

Kadar HCN kecambah koro komak dengan teknik elisitasi dapat dilihat pada Gambar 9 dan Gambar 10.
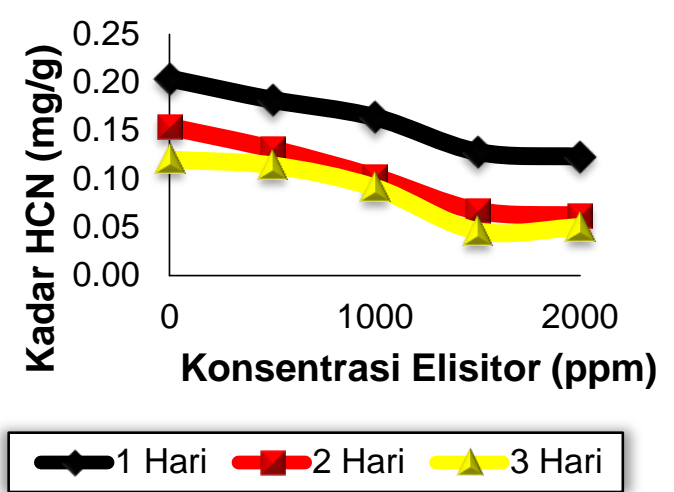

Gambar 9. Kadar HCN Kecambah Koro Komak dengan elisitor IPK
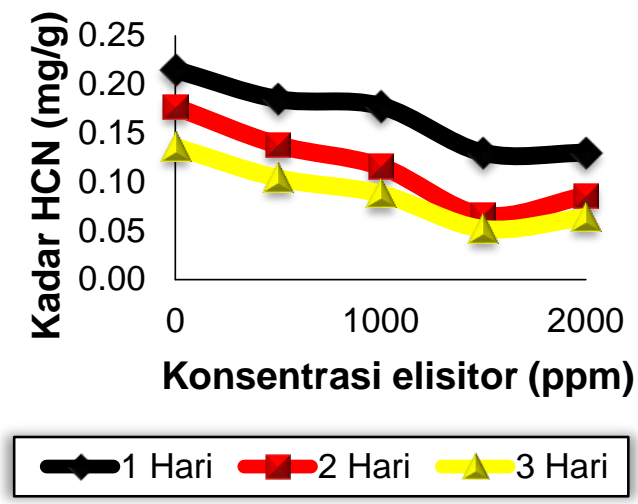

Gambar 10. Kadar HCN Kecambah Koro Komak dengan Elisitor Sukrosa

Dari Gambar 9 dan Gambar 10. dapat diketahui bahwa kadar HCN kecambah koro komak menurun paling tinggi pada 3 hari perkecambahan (72 jam). Hal ini diduga semakin lama waktu perkecambahan kadar HCN kecambah koro komak akan semakin hilang. Dari kedua gambar di atas terlihat kadar HCN terus menurun dari 1 hari, 2 hari, dan 3 hari perkecambahan.

Kadar HCN kecambah koro komak yang terendah dengan elisitor IPK terdapat pada 3 hari perkecambahan dengan konsentrasi elisitor $1.500 \mathrm{ppm}$ sebesar 0,046 $\mathrm{mg} / \mathrm{g}$. Begitu juga dengan elisitor sukrosa diperoleh kadar $\mathrm{HCN}$ terendah pada 3 hari perkecambahan dengan konsentrasi 1.500 ppm sebesar $0,054 \mathrm{mg} / \mathrm{g}$

Dari Tabel 2 terlihat bahwa konsentrasi elisitor semakin tinggi maka kadar HCN yang dihasilkan semakin rendah. Menurut (Contin et al, 1999) menjelaskan bahwa elisitor dapat meningkatkan kandungan metabolit sekunder dengan dua cara, yaitu meningkatkan aktivitas enzim dan meningkatkan sintesis enzim yang terlibat dalam jalur biosintesis metabolit tertentu, maka pada penelitian ini ada kemungkinan elisitor meningkatkan aktivitas enzim glikosianidase sehingga dengan semakin meningkatnya penambahan konsentrasi elisitor maka akan semakin mengaktifkan kinerja enzim glukosianidase dalam menghidrolisis HCN selama perkecambahan sehingga kadar HCN dapat menurun. 


\section{Daya Cerna Pati}

Daya cerna pati merupakan persentase pati yang dihidrolisis enzim. Dari hasil pengamatan dapat diketahui bahwa daya cerna pati rata-rata kecambah koro komak dengan elisitor isolat protein sebesar 92,15\% dan daya cerna pati rata-rata kecambah koro komak dengan elisitor sukrosa sebesar 95,86\%.

Pada Gambar 11 terlihat bahwa elisitor sukrosa memiliki peranan lebih besar terhadap peningkatan daya cerna pati kecambah koro komak dibanding elisitor ISP. Hal ini dikarenakan elisitor sukrosa mampu menginduksi enzim-enzim yang berfungsi menghidrolisis pati sehingga menyebabkan daya cerna pati meningkat. Selain itu, perbedaan pengaruh ini juga disebabkan karena elisitor sukrosa memiliki ukuran molekul yang kecil dan sifatnya larut air sehingga larutan sukrosa lebih mudah terserap oleh jaringan koro komak. Dengan demikian elisitor sukrosa lebih efektif dalam peningkatan daya cerna pati kecambah koro komak.

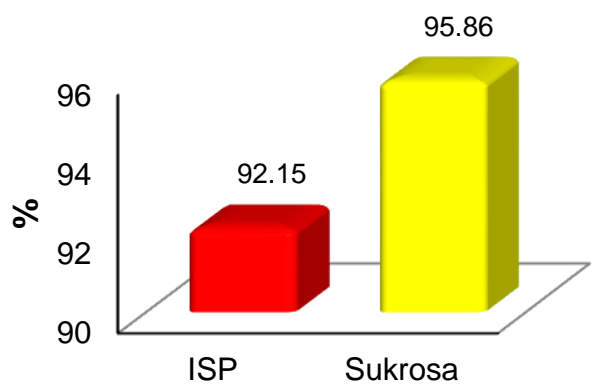

Gambar 11. Histogram daya cerna pati Kecambah Koro Komak Terelisitasi

\section{Daya Cerna Protein}

Daya cerna protein menunjukkan tingkat kemudahan protein untuk dipecah menjadi asam amino atau komponen pembentuknya sehingga mudah diserap tubuh. Dalam analisa ini digunakan BSA atau protein murni sebagai pembanding dari protein kecambah koro komak. Dari hasil pengamatan, BSA mempunyai daya cerna protein sebesar 72,3381\%. Kemudian, daya cerna protein kecambah koro komak dibandingkan dengan dengan BSA (dianggap memiliki daya cerna protein $100 \%$ ) dan diperoleh daya cerna protein kecambah koro komak dengan elisitor isolat protein sebesar 96,25\% dan dengan elisitor sukrosa sebesar $94,91 \%$.

Tingginya daya cerna protein kecambah koro komak ini menunjukkan bahwa protein kecambah koro komak dari hasil teknik elisitasi mudah diserap oleh tubuh karena proteinnya mudah untuk dihidrolisis atau dipecah menjadi asam amino atau komponen pembentuknya.

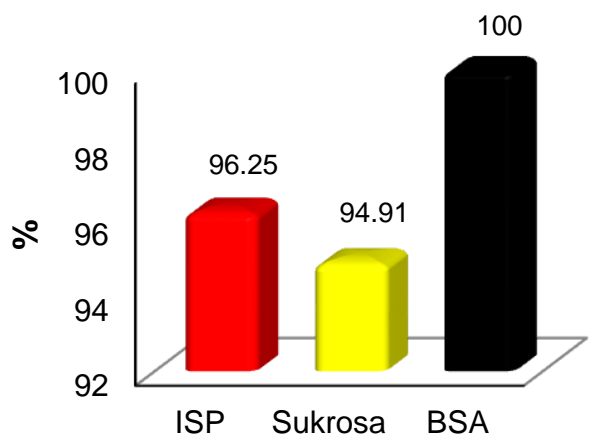

Gambar 12. Histogram Daya Cerna Protein Kecambah Koro Komak Terelisitasi

\section{Daya Cerna Protein}

Daya cerna protein menunjukkan tingkat kemudahan protein untuk dipecah menjadi asam amino atau komponen pembentuknya sehingga mudah diserap tubuh. Dalam analisa ini digunakan BSA atau protein murni sebagai pembanding dari protein kecambah koro komak. Dari hasil pengamatan, BSA mempunyai daya cerna protein sebesar $72,3381 \%$. Kemudian, daya cerna protein kecambah koro komak dibandingkan dengan dengan BSA (dianggap memiliki daya cerna protein $100 \%$ ) dan diperoleh daya cerna protein kecambah koro komak dengan elisitor isolat protein sebesar 96,25\% dan dengan elisitor sukrosa sebesar $94,91 \%$.

Tingginya daya cerna protein kecambah koro komak ini menunjukkan bahwa protein kecambah koro komak dari hasil teknik elisitasi mudah diserap oleh tubuh karena proteinnya mudah untuk dihidrolisis atau dipecah menjadi asam amino atau komponen pembentuknya. 


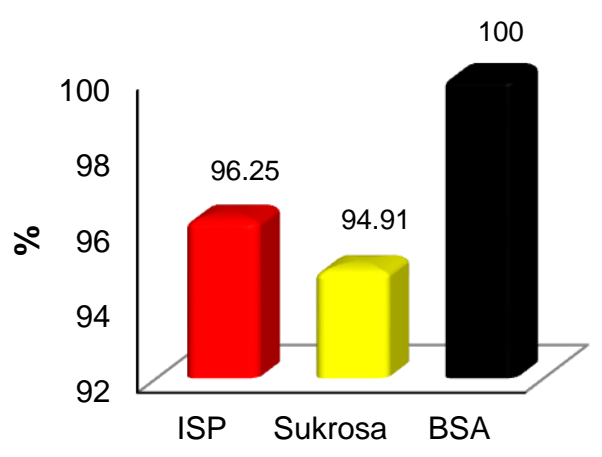

Gambar 12. Histogram Daya Cerna Protein Kecambah Koro Komak Terelisitasi

\section{Kadar Proksimat}

Kadar proksimat meliputi kadar protein, lemak, karbohidrat, abu, dan air. terlihat pada Gambar 13
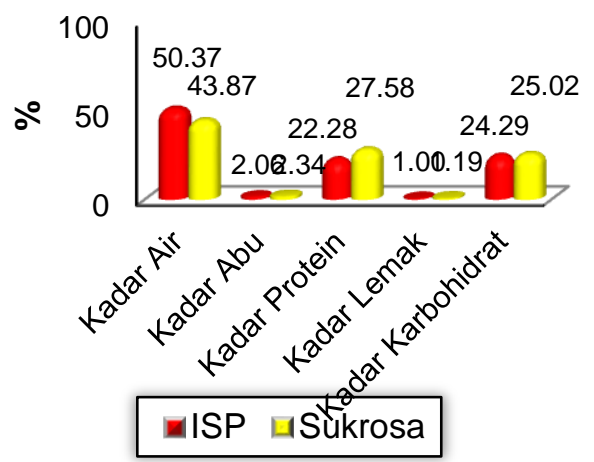

Gambar 13. Histogram Kadar Proksimat

Kecambah Koro Komak 1 Hari

Perkecambahan pada konsentrasi

Elisitor IPK dan Sukrosa 1.500 ppm

Biji polong komak memiliki kandungan air $9,6 \%$, abu $3,2 \%$, protein $24,9 \%$, lemak $0,8 \%$, karbohidrat $60,1 \%$ serta serat $1,4 \%$ per $100 \mathrm{~g}$ biji (Maesen dan Somaatmadja, 1993).

Dari Gambar 13. dapat diketahui bahwa kadar air bahan pada perkecambahan dengan elisitasi mengalami kenaikan. Hal ini dipengaruhi oleh perendaman dan penyiraman pada saat perkecambahan. Agar biji mampu berkecambah membutuhkan kadar air 30\% 55\% (Supriyanto, 1998). Kadar air kecambah koro komak pada penelitian ini berkisar antara $43,87-50,37 \%$. Sehingga kondisi tersebut merupakan kondisi yang cukup untuk perkecambahan dan mengaktifkan enzimenzim yang terkandung di dalamnya.
Kadar abu mengalami penurunan setelah dilakukan perkecambahan dan elisitasi. Pada biji polong kadar abu koro komak sebesar 3,2\%. Namun, setelah dilakukan perkecambahan dan elisitasi, kadar abu mengalami penurunan sekitar 2,06$2,34 \%$. Diduga beberapa senyawa dan mineral dalam bahan terlarut selama proses perendaman dan perkecambahan.

Kandungan lemak kecambah komak kecambah koro komak dengan elisitor IPK sebesar $1,00 \%$ dan dengan elisitor sukrosa sebesar $1,19 \%$.

Kadar protein kecambah koro komak dengan elisitor IPK sebesar 22,28\% dan dengan elisitor sukrosa sebesar 27,58\%.

Kadar karbohidrat kecambah koro komak dengan elisitor isolat protein sebesar $24,28 \%$ dan dengan elisitor sukrosa sebesar $25,02 \%$.

Karbohidrat dan protein mengalami penurunan selama perkecambahan dibandingkan sebelum dikecambahkan. Pada saat perkecambahan memerlukan energi yang sangat besar untuk proses pertumbuhan. Untuk memenuhi kebutuhan energi tersebut digunakan protein setelah cadangan karbohidrat menipis. Menurut Soetopo (2002), protein dihidrolisis menghasilkan berbagai asam amino bebas, salah satunya asam glutamin dan aspartat, senyawa-senyawa ini terutama dalam bentuk amidanya ditranslokasikan ke embrio.

\section{KESIMPULAN}

1. Jenis dan konsentrasi elisitor ISP dan sukrosa berpengaruh terhadap mutu kecambah koro komak.

2. Lama perkecambahan yang terbaik dalam meningkatkan mutu kecambah koro komak yaitu 1 hari perkecambahan.

3. Kombinasi perlakuan terbaik adalah A2B4 (elisitor sukrosa konsentrasi 1.500 ppm) pada 1 hari perkecambahan menghasilkan kecambah koro komak dengan mutu terbaik, yaitu kadar vitamin C sebesar $1,4090 \mathrm{mg} / \mathrm{g}$; kadar $\beta$-karoten $0,2160 \mu \mathrm{g} / \mathrm{g} ;$ total polifenol 0,0408 $\mu \mathrm{mol} / \mathrm{mg}$; aktivitas antioksidan 2,2959 $\mu \mathrm{mol} / \mathrm{g}$; kadar $\mathrm{HCN}$ (zat racun) 0,1301 mg/g; kadar air 43,8729 \%; kadar abu 2,3357\%; kadar protein 27,58\%; kadar lemak 1,19\%; kadar karbohidrat 25,02\%; 
daya cerna pati $95,86 \%$; dan daya cerna protein $94,91 \%$.

\section{DAFTAR PUSTAKA}

Andarwulan, N., Fardiaz, Wattimena, dan Shetty. 1999. Antioxidant Activity Associated with Lippid an Phenolik Mobilization During Seed Germination of Pangium Edule Reinw. J. Agric. Food Chem, 47: 3158-3163.

Apriliana, Reny. 2007. Studi Optimasi Proses Perkecambahan Koro pedang

(Canavalia ensiformis (L.) DC.) Kajian Kondisi Perkecambahan dan

Konsentrasi Elisitor Sukrosa. Jember : Fakultas Teknologi Pertanian

Universitas Jember.

Bravo, L. 1998. Polyphenols : Chemistry, Dietary Sources, Metabolism, and

Nutritional Significance. Nutrition Reviews 56 : 317-332.

Contin, A., Heijden, R. V. D., dan Verpoorte, R. 1999. Effects of Alkoloid Precusor Feeding and Elicitation on The Accumulation of Secologanin in a Catharanthus roseus Dell suspension culture. Plant Cell Tiss. \& Org. Cult., 56: 111-119.

Fitriani, A. 2003. Kandungan Ajmalisin pada Kultur Kalus Catharanthus roseus (L.)

G. Don setelah Dielisitasi Homogenat Jamur Pythium Aphanidermatum

Edson Fitzp. Tesis Magister, Jurusan Biologi. Bandung: Institut Teknologi Bandung

Gadow, A., Joubert, E., dan Hansman, C. F. 1997. Comparison of The Antioxidant Activity of Aspalathin with That of Other Plant Phenols of Rooibos Tea (Aspalathin Linearis). J. Agric. Food Chem, 45: 832-630.

Gasperz, V. 1991. Metode Rancangan Percobaan untuk Ilmu-Ilmu Pertanian. Bandung: CV. Armico

Maesen, L. J. G. dan Somaatmadja. 1993. Prosea Sumber Daya Nabati Asia Tenggara I. Jakarta: PT. Gramedia Pustaka Utama.

Novijanto, Noer. 1996. Pengaruh Suhu dan Lama Perendaman terhadap Mutu Kecambah. Jember: Badan Penelitian Universitas Jember
Randhir, Reena, Yuan-Tong Lin dan Kalidas Shetty. 2004. Phenolics, Their Antioxidants and Antimicrobial Activity ini Dark Germinated Fenugreek Sproust in Response to Peptide and Phytochemical Elicitors.http://www.healthyeatingclub. com/APJCN/Volume13/Vol13.3/finishe d/Randhir/pdf.

Rubatzky, V. E. dan Yamaghuci, M. 1998. Sayuran Dunia: Prinsip, Produksi, dan Gizi, Jilid 2. Bandung: Institut Teknologi Bandung.

Rusdianto, A. S. 2004. Karakterisasi Biji dan Protein Koro Komak (Lablab purpureus (L) Sweet) sebagai Sumber Protein. Jember: Jurusan Teknologi Hasil Pertanian Fakultas Teknologi Pertanian, Universitas Jember.

Setyati, Dwi. 1999. Perkecambahan Biji Tumbuhan Penyusunan VegetasiPantai. Jember: Badan Penelitian, Universitas Jember.

Soetopo, L. 2002. Teknologi Benih. Jakarta: PT. Raja Grafindo Persada.

Subagio, A., Yuli, W., dan Wiwik, S. W. 2002. Protein Albumin dan Globulin dari Beberapa Jenis Koro-Koroan di Indonesia. Jurnal Seminar Nasional PATPI, 30-31 Juli: 135-140. Malang.

Sudarmadji, S. 1984. Analisa Bahan Makanan dan Pertanian. Yogyakarta: Liberty bekerjasama dengan Pusat Antar Universitas pangan dan Gizi Universitas Gadjah Mada.

Sudarmadji, S., Haryono, B., dan Suhardi. 1997. Prosedur Analisa Bahan Makanan dan Pertanian. Yogyakarta: Liberty.

Supriyanto. 1998. Tepung Kecambah sebagai Produk Alternatif Biji KacangKacangan Berkulit Keras. Yogyakarta: Prosiding Seminar Nasional PATPI.

Susanto, T. dan Saneto, B. 1994. Teknologi Pengolahan Hasl Pertanian. Surabaya: PT. Bina Ilmu.

Sutardi. 1998. Perubahan Kadar Asam Fitat dan Aktivitas Fitase selama Perkecambahan Beberapa Jenis Kacang-Kacangan. Yogyakarta: Prosiding Seminar Nasional PATPI.

Tejasari, Sukatiningsing, dan Praptiningsih, Y. 2006. Evaluasi Gizi dalam 
Pengolahan. Jember: Jurusan Teknologi Hasil Pertanian Fakultas Teknologi Pertanian Universitas Jember.

Yuliana, A. 2003. Pengaruh Penambahan Polisakarida sebagai Elisitor untuk Produksi Antioksidan selama Germinasi Biji Kacang Tunggak dan Kedelai Hitam. Bogor: IPB. 